\title{
Efektivitas guided discovery menggunakan pendekatan kontekstual ditinjau dari kemampuan berpikir kritis, prestasi, dan self-efficacy
}

\section{Imaludin Agus *}

Institut Agama Islam Negeri Kendari.

Jalan Sultan Qaimuddin No.17, Baruga, Kota Kendari, Sulawesi Tenggara 93563, Indonesia

E-mail: imal.udin@yahoo.co.id

* Corresponding Author

\section{ARTICLE INFO}

\section{Article history}

Received: 16 June 2017;

Revised: 24 Sept. 2019;

Accepted: 6 Nov. 2019

\section{Keywords}

guided discovery, pendekatan kontekstual, berpikir krits, prestasi, selfefficacy; contextual approach, critical thinking, achievement

\section{ABSTRACT}

Penelitian ini bertujuan untuk mendeskripsikan perbedaan keefektifan guided discovery meggunakan pendekatan kontekstual dan konvensional ditinjau dari kemampuan berpikir kritis, prestasi belajar, dan self-efficacy matematika siswa SMP. Jenis penelitian ini adalah quasi experiment dengan pretest-posttest nonequivalent group design. Populasi dalam penelitian ini adalah siswa kelas VIII SMP Negeri di Kontukowun, kabupaten Muna dan kelas VIII-1 dan Kelas VIII2 dipilih secara acak sebagai sampel. Untuk mengetahui keefektifan guided discovery menggunakan pendekatan kontekstual dan konvensional menggunakan uji one sample t-test, sedangkan untuk perbedaan keefektifan metode pembelajaran menggunakan uji two group manova. Jika terdapat perbedaan maka dilanjutkan dengan uji perbandingan menggunakan independent sample $t$-test. Hasilnya menunjukkan bahwa guided discovery menggunakan pendekatan kontekstual efektif ditinjau dari kemampuan berpikir kritis, prestasi belajar, dan self-efficacy; metode konvensional tidak efektif ditinjau dari kemampuan berpikir kritis, prestasi belajar, dan self-efficacy; dan guided discovery menggunakan pendekatan kontekstual lebih efektif dibandingkan konvensional ditinjau dari kemampuan berpikir kritis, prestasi belajar, dan self-efficacy.

The aim of the study aims to describe the effectiveness of guided discovery using the contextual approach in terms of critical thinking ability, learning achievement and self-efficacy in the mathematics of junior high school students. The study was quasi-experiment with pretest-posttest nonequivalent group design method. The population in this research was all 8th-grade students from one public junior high school in Kontukowuna, Muna Regency, Indonesia and class VIII-1 and VIII-2 were randomly selected as a sample. One sample t-test was used to determine the effectiveness of the guided discovery using the contextual approach and the conventional method. Whereas, two groups of Manova was used to know the difference between the learning methods. Then, if the result showed there is a significant difference between the two classes, the independent sample t-test was administered. Result of the study indicates that the guided discovery using the contextual approach is effective in terms of critical thinking ability, learning achievement, and self-efficacy; the conventional method is not effective in terms of critical thinking ability, learning achievement, and self-efficacy; and the guided discovery using contextual approach is more effective than conventional in terms of critical thinking ability, learning achievement, and self-efficacy.

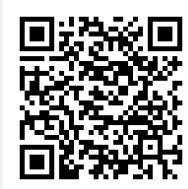

How to Cite: Agus, I. (2019). Efektivitas guided discovery menggunakan pendekatan kontekstual ditinjau dari kemampuan berpikir kritis, prestasi, dan self-efficacy. Jurnal Riset Pendidikan Matematika, 6(2) 120-132. doi:https://doi.org/10.21831/jrpm.v6i2.14517 


\section{PENDAHULUAN}

Pendidikan memiliki peranan yang esensial dalam mewujudkan sumber daya manusia (SDM) yang kompetibel serta kompetitif. Pendidikan pula dapat dikatakan sebagai faktor penentu kualitas SDM yang berimplikasi pada kemajuan suatu bangsa. Upaya rekonstruksi pada ranah pendidikan menjadi suatu keharusan bagi seluruh elemen yang terlibat di dalamnya, sehingga tujuan pendidikan nasional seperti yang tertulis dalam Undang-Undang Dasar Negara Republik Indonesia Tahun 1945 yaitu mencerdaskan kehidupan bangsa dapat terwujud.

Salah satu mata pelajaran yang wajib dipelajari pada jenjang pendidikan adalah matematika. Matematika sebagai bahasa universal, pengetahuan universal serta menjadi dasar bagi perkembangan teknologi modern (Van de Walle, 2010, p. 102). Selain itu, matematika juga sebagai pengetahuan yang dapat mengakomodir kemampuan berpikir, sebab ciri khas dari matematika yaitu proses bernalar dan penarikan kesimpulan yang logis, sehingga tidak hanya bermanfaat pada subtansi matematika melainkan juga pada kehidupan sehari-hari (Muijs et al., 2011, p. 333; Muijs \& Reynolds, 2005).

Melihat pentingnya matematika, maka mata pelajaran ini dipelajari siswa mulai dari sekolah dasar yang bertujuan memfasilitasi siswa dalam meningkatkan kemampuan berpikir. Hal ini sesuai dengan tujuan pembelajaran matematika yaitu memfasilitasi siswa dalam proses berpikir secara logis, analitis, sistematis, kritis dan kreatif (Peraturan Menteri Pendidikan dan Kebudayaan Republik Indonesia Nomor 21 Tahun 2016 tentang Standar Isi Pendidikan Dasar dan Menengah, 2016). Selain itu, (Marsigit et al., 2015 , p. 225) menyatakan bahwa inovasi pembelajaran matematika diperlukan dalam menyongsong abad 21, agar siswa memiliki kemampuan 4C yaitu Communication, Collaboration, Critical Thinking, dan Creativity. Hal ini semakin mempertegas bahwa kemampuan berpikir kritis dan matematika bukanlah suatu yang dapat dipisahkan. Hal tersebut diperkuat pendapat (Chukwuyenum, 2013) yang manyatakan bahwa kemampuan berpikir kritis memiliki hubungan signifikan dengan prestasi matematika siswa.

Kemampuan berpikir kritis adalah kemampuan yang melibatkan proses pengujian dan evaluasi secara hati-hati serta membantu menghindarkan bias kognitif yang dapat menyebabkan pengambilan keputusan yang kurang tepat (Fahim \& Masouleh, 2012, pp. 135-137). Seseorang yang memiliki kemampuan berpikir kritis mampu melihat wilayah yang masih abu-abu, sehingga diperlukan penelusuran lanjutan untuk mengetahuinya. Oleh karena itu, kemampuan berpikir kritis menjadi variabel yang harus dimiliki oleh siswa sebagai dasar dalam pengambilan keputusan baik dalam pembelajaran matematika maupun kehidupan sehari-hari.

Memperhatikan manfaat matematika dalam mengakomodir kemampuan berpikir kritis, maka pembiasaan kemampuan tersebut diintegrasikan dalam pembelajaran matematika menjadi keharusan. Guru diharapkan dapat menjadi fasilitator, mediator, dan desainer pembelajaran yang memilih dan memilah metode pembelajaran yang tepat sesuai dengan tingkat berpikir siswa, sehingga mengarahkan siswa untuk mencapai prestasi terbaiknya, serta siswa sebagai subjek yang aktif memperoleh pengetahuannya sendiri. Hal ini sesuai dengan prinsip belajar modern dan asumsi dasar Kurikulum 2013 bahwa belajar merupakan proses konstruk kognitif yang diperoleh siswa melalui pengalamannya (Fithriyyati \& Maryani, 2018; Hosnan \& Sikumbang, 2014, p. 282).

Pada kenyataannya, (Mahmudi, 2009) menyatakan bahwa sistem pembelajaran matematika di sekolah masih bersifat mekanistik, sehingga belum melibatkan siswa secara aktif mengkonstruksi pengetahuannya. Selain itu, hasil studi oleh Trends International Mathematics and Science Study (TIMSS) tahun 2011 menyatakan bahwa kemampuan siswa Indonesia dalam menyelesaikan soal matematika berkisar pada soal yang sifatnya faktual dan prosedural (Mullis et al., 2012). Begitu pula pada salah satu SMP Negeri di Kontukowuna, berdasarkan observasi yang dilakukan oleh peneliti, pembelajaran matematika di kelas belum melibatkan siswa dalam berpikir kritis. Hal ini terindikasi melalui tidak aktifnya siswa dalam mengkonstruksi pengetahuannya selama pembelajaran, sebab peran guru masih sangat mendominasi. Selain itu, soal latihan yang diberikan guru masih bersifat penerapan konsep dan prinsip, sehingga siswa belum terbiasa mengerjakan soal yang melibatkan proses berpikir. Kondisi ini diduga menjadi penyebab kemampuan berpikir kritis siswa rendah, sehingga berimplikasi pada prestasi belajar matematika yang tidak optimal.

Prestasi belajar matematika berkaitan dengan tingkat keberhasilan siswa dalam mempelajari kompetensi dasar tertentu dalam kurun waktu yang ditentukan. Keberhasilan tersebut terlihat dari pengetahuan, keterampilan, dan kemampuan yang dimiliki siswa setelah melalui serangkaian pembelajaran di kelas. Sebagaimana dikemukakan oleh (Nitko \& Brookhart, 2011, p. 497) bahwa prestasi adalah penge- 


\section{Jurnal Riset Pendidikan Matematika, 6 (2), 2019 - 122}

Imaludin Agus

tahuan, keterampilan dan kemampuan siswa yang diperoleh sebagai hasil proses pembelajaran. Berdasarkan ulasan tersebut maka prestasi belajar diartikan sebagai output dari suatu pembelajaran, sehingga prestasi belajar yang baik membutuhkan perencanaan dan aktualisasi pembelajaran yang baik pula.

Hasil TIMSS tahun 2011 menunjukkan bahwa kemampuan matematika siswa Indonesia secara umum berada di level bawah yakni dengan median $43 \%$ dibandingkan skor internasional dengan median sebesar 75\% (Setiadi et al., 2012, pp. 53-56). Secara rangking, Indonesia berada pada peringkat 41 dari 45 peserta (Setiadi et al., 2012, p. 46). Selain itu, laporan hasil Ujian Nasional oleh Badan Standar Nasional Pendidikan (BSNP) untuk mata pelajaran matematika SMP secara nasional nilai rata-rata mengalami penurunan yakni 56,60 pada tahun 2014/2015 (Badan Standar Nasional Pendidikan, 2015) menjadi 51,01 pada tahun 2015/2016 (Badan Standar Nasional Pendidikan, 2016). Tidak hanya itu, pada Provinsi Sulawesi Tenggara khususnya di Kabupaten Muna menunjukkan hal yang sama yaitu nilai ratarata 67,23 pada pada tahun 2014/2015 (Badan Standar Nasional Pendidikan, 2015) menjadi 55,26 pada tahun 2015/2016 (Badan Standar Nasional Pendidikan, 2016). Berdasarkan kedua hasil tersebut maka pembelajaran matematika di Indonesia belum memperlihatkan hasil yang memuaskan.

Selain kedua aspek kognitif tersebut, faktor yang mempengaruhi keberhasilan siswa dalam belajar matematika adalah aspek afektif. Salah satu aspek afektif yang diduga memiliki pengaruh signifikan dalam pembelajaran adalah self-efficacy (Schunk, 2012, p. 148). (Slavin, 2014; Zimmerman et al., 1996) menyatakan self-efficacy sebagai variabel penting dimiliki oleh siswa. Siswa yang memiliki self-efficacy yang tinggi cenderung menggunakan strategi belajar kognitif. Kaitanya dengan self-efficacy matematika, (Pajares \& Graham, 1999, p. 126) menyatakan bahwa self-efficacy merupakan keyakinan siswa terhadap kemampuan, keberhasilan, dan kegigihan mereka dalam belajar dan mengerjakan segala tugastugas matematika serta keyakinan atas manfaat matematika pada kehidupan sehari-hari. Oleh karena itu, self-efficacy merupakan variabel penting dimiliki oleh siswa yang berimplikasi pada peningkatan prestasi belajar matematika siswa. Sebagaimana hasil penelitian (Liu \& Koirala, 2009) bahwa terdapat hubungan yang signifikan antara self-efficacy dengan prestasi belajar matematika siswa.

Pengaruh self-efficacy terhadap prestasi belajar siswa terindikasi melalui berbagai persoalan pada diri siswa. Berdasarkan hasil observasi, persoalan tersebut antara lain: siswa tidak yakin dengan kemampuan yang dimiliki ketika belajar dan menyelesaikan tugas-tugas matematika; siswa selalu ragu ketika menyampaikan hasil pekerjaannya, dengan alasan takut salah; siswa belum mampu belajar materi matematika dengan tingkat kesulitan yang meningkat; serta siswa belum mampu dengan yakin bertanya dan menyampaikan pendapat ketika diberi kesempatan. Selain itu, mindset negatif siswa terhadap matematika sebagai mata pelajaran yang sulit memiliki pengaruh terhadap keyakinan siswa terhadap matematika. Sebagaimana (Muijs et al., 2011, p. 333; Muijs \& Reynolds, 2005) menyatakan bahwa masih banyak siswa tidak tertarik dengan pembelajaran matematika serta mempertanyakan relevansi mata pelajaran ini dengan kehidupan nyata.

Menyikapi berbagai fakta dan permasalahan yang berkaitan dengan proses pembelajaran matematika di sekolah dalam mengakomodir kemampuan berpikir kritis, prestasi belajar, dan self-efficacy matematika siswa, maka diperlukan solusi yang bertujuan untuk meningkatkan kualitas pembelajaran di kelas. Solusi yang ditawarkan adalah dengan memilih metode, model, strategi atau pendekatan pembelajaran yang dapat merubah paradigma pembelajaran dari berpusat pada guru menjadi berpusat pada siswa, serta menjadikan siswa sebagai agen pembelajaran yang aktif mengkonstruksi pengetahuannya sendiri. Kondisi ini akan membuka ruang ideal bagi berkembangnya kemampuan berpikir siswa. Selain itu, keterlibatan siswa selama proses pembelajaran juga dapat menumbuhkan keyakinan pada diri siswa atas kemampuan yang dimiliki. Dengan demikian, kemampuan berpikir kritis, self-efficacy dapat ditingkatkan ke arah yang lebih baik dan diharapkan akan berimbas pada tercapainya prestasi belajar yang baik pula.

Salah satu metode pembelajaran yang mampu menampung semua aspek tersebut adalah metode guided discovery learning (GDL). GDL merupakan bagian dari pembelajaran konstruktivisme modern, dimana siswa menyusun dan mengkonstruksi pengetahuannya (Uside et al., 2013, p. 353). Menurut Balim (2009, p.2) GDL adalah metode pembelajaran yang melibatkan siswa secara aktif menemukan berdasarkan aktifitas dan pengamatan mereka. Hasil temuan tersebut berupa konsep dan prinsip, maupun hubungan antar konsep (Eggen \& Kauchak, 2010). Keterlibatan siswa secara aktif dalam proses penemuan konsep dan prinsip dalam belajar matematika berpeluang meningkatnya kemampuan berpikir kritis dan self-efficacy siswa. Dengan terpenuhinya kedua aspek tersebut berpotensi meningkatkan 
prestasi belajar matematika siswa. Hasil penelitian (Imawan, 2015; Siregar \& Marsigit, 2015) menyimpulkan bahwa metode GDL efektif jika ditinjau dari kemampuan berpikir kritis, prestasi belajar, selfefficacy matematika. Selain metode pembelajaran, pemilihan pendekatan yang digunakan dalam metode menjadi faktor yang penting. Salah satu pendekatan yang direkomendasikan agar mampu melihat relevansi matematika dalam kehidupan sehari-hari adalah pendekatan kontekstual (Peraturan Menteri Pendidikan dan Kebudayaan Republik Indonesia Nomor 21 Tahun 2016 tentang Standar Isi Pendidikan Dasar dan Menengah, 2016). (Komalasari, 2010, p. 7; Yildiz \& Baltaci, 2016, p. 155) mengemukakan bahwa pendekatan kontekstual merupakan pendekatan pembelajaran yang mengaitkan antara kompetensi atau materi yang dipelajari siswa di kelas dengan kehidupan nyata baik dalam lingkungan keluarga, masyarakat, maupun negara yang bertujuan menemukan makna dari yang telah dipelajari.

John Dewey mengungkapkan bahwa siswa akan belajar dengan baik jika apa yang dipelajari memiliki relevansi antara pengetahuan yang mereka ketahui dengan peristiwa yang ada dalam lingkungan sekeliling mereka (Hosnan \& Sikumbang, 2014, p. 267). Hal ini berpotensi untuk dapat meningkatkan kemampuan berpikir kritis dan self-efficacy siswa. Dengan terakomodirnya kedua aspek tersebut diharapkan mampu menjadikan prestasi belajar matematika siswa termaksimalkan. Sebagaimana hasil penelitian (Kurniati et al., 2015) bahwa pendekatan contextual teaching and learning (CTL) efektif ditinjau dari kemampuan berpikir kritis. Sejalan dengan itu, (Jhonson, 2014, p. 65) mengemukakan bahwa salah satu komponen pendekatan kontekstual yaitu berpikir kritis. Selain itu, (Putri \& Santosa, 2015) menyimpulkan bahwa pembelajaran REACT efektif untuk meningkatkan prestasi belajar dan selfefficacy matematika siswa. Oleh karena itu, penggunaan pendekatan kontekstual yang dikombinasikan dengan metode pembelajaran GDL merupakan pilihan yang diduga tepat, agar tercipta iklim belajar yang melibatkan siswa aktif dalam proses penemuan, serta memahami bahwa betapa bermanfaatnya matematika dalam kehidupan mereka.

Penelitian tentang penerapan metode GDL dan pendekatan kontekstual secara parsial telah dilakukan oleh beberapa pihak dengan hasil yang meningkatkan kemampuan berpikir kritis, prestasi belajar dan self-efficacy matematika siswa. Namun, pengkombinasian antara metode GDL dan pendekatan kontekstual belum dilakukan untuk meningkatkan kemampuan berpikir kritis, prestasi belajar dan self-efficacy. Selain itu, penelitian dengan metode GDL menggunakan pendekatan kontekstual juga belum dilaksanakan pada SMP Negeri di Kontukowuna dengan karakteristik siswa yang memiliki kemampuan berpikir kritis rendah. Untuk itu, peneliti ini bertujuan untuk mendeskipsikan efektivitas metode GDL menggunakan pendekatan kontekstual ditinjau dari kemampuan berpikir kritis, prestasi belajar, dan self-efficacy matematika siswa SMP.

\section{METODE}

Jenis penelitian ini adalah eksperimen semu (quasi experiment) dengan pretest-posttest nonequivalent control group design. Penelitian ini dilaksanakan di SMP Negeri Kontukowuna, Kabapaten Muna, Sulawesi Tenggara pada semester genap tahun ajaran 2015/2016. Populasi penelitian adalah seluruh siswa kelas VIII Tahun Ajaran 2015/2016. Sampel penelitian ditentukan secara acak (simple random sampling), sehingga terpilih kelas VIII-1 dan VIII-2 sebagai sampel penelitian.

Instrumen yang digunakan dalam penelitian ini terdiri atas instrumen tes prestasi belajar sebanyak 25 butir soal pilihan ganda dan tes kemampuan berpikir kritis sebanyak 4 butir soal essay dengan mengacu pada standar kompetensi Kurikulum Tingkat Satuan Pendidikan (KTSP) materi bangun ruang sisi datar. Sedangkan instrumen non tes terdiri atas angket self-efficacy sebanyak 12 butir pernyataan positif dan 12 butir pernyataan negatif dan lembar keterlaksanaan pembelajaran.

Analisis data yang digunakan yaitu analisis data deskriptif dan inferensial. Analisis data deskriptif digunakan untuk mendeskripsikan data kemampuan berpikir kritis, prestasi belajar, dan self-efficacy matematika sebelum dan sesudah perlakuan. Kriteria ketuntasan untuk masing-masing variabel yaitu rata-rata nilai kemampuan berpikir kritis dan prestasi belajar siswa minimal 70 yang didasarkan pada nilai kriteria ketuntasan minimal (KKM). Sedangkan self-efficacy matematika siswa sebesar 81,6 (Tinggi) sesuai dengan kriteria yang diharapkan. Data self-efficacy matematika siswa yang diperoleh dikategorisasikan berdasarkan kriteria yang digunakan. Kategorisasi yang digunakan disajikan pada Tabel 1. 
Tabel 1. Kriteria Self-efficacy Matematika Siswa

\begin{tabular}{cc}
\hline Interval & Kategori \\
\hline $100,8<\mathrm{X} \leq 120$ & Sangat Tinggi \\
$81,6<\mathrm{X} \leq 100,8$ & Tinggi \\
$62,4<\mathrm{X} \leq 81,6$ & Sedang \\
$43,2<\mathrm{X} \leq 62,4$ & Rendah \\
$\mathrm{X} \leq 43,2$ & Sangat Rendah \\
\hline
\end{tabular}

(Widoyoko, 2014, p. 258)

Analisis data inferensial digunakan untuk membuktikan secara statistik hipotesis penelitian yang diajukan serta menjawab rumusan masalah yang ditetapkan. Untuk mengetahui keefektifan metode pembelajaran ditinjau dari kemampuan berpikir kritis, prestasi belajar, dan self-efficacy matematika siswa, digunakan one sample t test dengan bantuan program SPSS. Adapun hipotesisnya yaitu:

Kemampuan berpikir kritis dan prestasi:

$\mathrm{H}_{0}: \mu \leq 70$

$\mathrm{H}_{\mathrm{a}}: \mu>70$

Self-efficacy:

$\mathrm{H}_{0}: \mu \leq 81,6$

$\mathrm{H}_{\mathrm{a}}: \mu>81,6$

Kriteria keputusan untuk menolak hipotesis nol $\left(\mathrm{H}_{0}\right)$ yaitu jika $\mathrm{t}>\mathrm{t}_{\alpha, \mathrm{n}-1}, \alpha=0.05$ (Walpole, 1990, p. 303).

Selanjutnya dilakukan uji perbedaan keefektifan metode pembelajaran pada data pretest dan posttest. Uji perbedaan keefektifaan pada data pretest bertujuan untuk mengetahui kondisi awal kedua kelas sampel (kelas eksperimen vs. kelas kontrol). Sedangkan, pada data posttest bertujuan untuk melihat perbedaan keefektifan antara metode pembelajaran GDL menggunakan pendekatan kontekstual dan metode konvensional ditinjau dari kemampuan berpikir kritis, prestasi belajar, dan self-efficacy matematika siswa. Adapun hipotesis penelitiannya adalah sebagai berikut, dengan KBK merupakan Kemampuan berpikir kritis; PB adalah Prestasi belajar; dan SE adalah Self-efficacy

$\mathrm{H}_{0}:\left(\begin{array}{c}\mu_{(\mathrm{KBK}) 1} \\ \mu_{(\mathrm{PB}) 1} \\ \mu_{(\mathrm{SE}) 1}\end{array}\right)=\left(\begin{array}{c}\mu_{(\mathrm{KBK}) 2} \\ \mu_{(\mathrm{PB}) 2} \\ \mu_{(\mathrm{SE}) 2}\end{array}\right)$
$\mathrm{H}_{\mathrm{a}}:\left(\begin{array}{c}\mu_{(\mathrm{KBK}) 1} \\ \mu_{(\mathrm{PB}) 1} \\ \mu_{(\mathrm{SE}) 1}\end{array}\right) \neq\left(\begin{array}{c}\mu_{(\mathrm{KBK}) 2} \\ \mu_{(\mathrm{PB}) 2} \\ \mu_{(\mathrm{SE}) 2}\end{array}\right)$

Statistik uji yang digunakan untuk menguji perbedaan antara dua kelompok metode pembelajaran (eksperimen vs. kontrol) digunakan uji MANOVA dengan bantuan program SPSS. Jika hasil uji statistik menolak $H_{0}$ maka pengujian dilanjutkan pada tahap uji lanjut univarit (post hoc) menggunakan uji $t$. Adapun hipotesisnya adalah:

$\mathrm{H}_{0}: \mu_{i 1} \leq \mu_{i 2}$

$\mathrm{H}_{\mathrm{a}}: \mu_{i 1}>\mu_{i 2}$

Statistik uji yang digunakan untuk membandingkan keefektifan dua kelompok metode pembelajaran dengan satu variabel terikat (univariat) yaitu uji independent $t$ test dan perhitungannya menggunakan bantuan program SPSS.

Sebelum dilakukan uji hipotesis, terlebih dahulu dilakukan uji asumsi baik univariat maupun multivariat. Uji normalitas univariat menggunakan uji kolmogrov-smirnov, sedangkan normalitas multivariat menggunakan uji jarak mahalanobis. Kriteria yang digunakan yaitu apabila sekitar $50 \%$ nilai $d_{i}^{2}$ $<\chi_{p, 0.5}^{2}$ maka data tersebut berdistribusi normal multivariat (Johnson \& Wichern, 2002). Uji homogenitas univariat dengan menggunakan uji levene, sedangkan uji homogenitas multivariat menggunakan uji Box's M (Stevens, 2009, p. 230). Semua pengujian menggunakan taraf signifikan $\alpha=$ $5 \%$. 


\section{HASIL DAN PEMBAHASAN}

\section{Analisis Deskriptif}

Analisis data deskriptif dilakukan pada dua data yang diperoleh sebelum (pretest) dan sesudah perlakuan (posttest). Data pretest dan posttest berupa nilai kemampuan berpikir kritis, prestasi belajar, dan self-efficacy matematika siswa. Data pretest dan posttest tersebut digunakan untuk melihat keefektifan metode GDL menggunakan pendekatan kontekstual dan metode pembelajaran konvensional ditinjau dari kemampuan berpikir kritis, prestasi belajar, dan self-efficacy matematika siswa.

Data hasil pretest dan posttest kemampuan berpikir kritis matematika untuk kelas eksperimen (GDL-Kon) dan kelas konvensional disajikan pada Tabel 2.

Tabel 2. Data Hasil Pretest dan Posttest Kemampuan Berpikir Kritis Matematika Siswa

\begin{tabular}{lcccc}
\hline \multirow{2}{*}{ Deskripsi } & GDL-Kon & \multicolumn{3}{c}{ Konvensional } \\
\cline { 2 - 5 } & Pre & Post & Pre & Post \\
\hline Mean & 27,66 & 76,00 & 26,96 & 56,59 \\
Standar Deviasi & 16,21 & 11,69 & 13,31 & 18,93 \\
Varians & 262,69 & 136,76 & 177,39 & 358,35 \\
Maksimum & 59,38 & 96,88 & 56,25 & 100 \\
Minimum & 9,37 & 46,88 & 6,25 & 28,13 \\
Ketuntasan (\%) & 0 & 89,29 & 0 & 35,71 \\
\hline
\end{tabular}

Berdasarkan analisis deskriptif yang disajikan pada Tabel 2, dapat dilihat bahwa nilai rata-rata kemampuan berpikir kritis pada kelas GDL-Kon dan konvensional mengalami peningkatan. Nilai ratarata pretest kemampuan berpikir kritis pada kelas GDL-Kon sebesar 27,66 mengalami peningkatan menjadi 76,00 pada posttest, dengan persentase ketuntasan sebesar $0 \%$ pada pretest meningkat menjadi $89,29 \%$ (25 siswa) yang tuntas pada posttest. Sedangkan, pada kelas konvensional sebesar 26,96 pada pretest meningkat menjadi 56,59 pada posttest, dengan presentasi ketuntasan sebesar $0 \%$ pada pretest meningkat menjadi $35,71 \%$ (10 siswa) yang tuntas pada posttest. Data hasil pretest dan posstest prestasi belajar matematika siswa untuk kedua kelas disajikan pada Tabel 3.

Tabel 3. Data Hasil Pretest dan Posttest Prestasi Belajar Matematika Siswa

\begin{tabular}{lcccc}
\hline \multirow{2}{*}{ Deskripsi } & GDL-Kon & \multicolumn{3}{c}{ Konvensional } \\
\cline { 2 - 5 } & Pre & Post & Pre & Post \\
\hline Mean & 42,96 & 77,71 & 39,7 & 66,43 \\
Standar Deviasi & 9,65 & 9,7 & 8,07 & 12,57 \\
Varians & 93,04 & 94,14 & 65,14 & 158,03 \\
Maksimum & 72 & 88 & 60 & 92 \\
Minimum & 28 & 44 & 28 & 32 \\
Ketuntasan (\%) & 3,7 & 89,29 & 0 & 64,29 \\
\hline
\end{tabular}

Berdasarkan Tabel 3 diperoleh bahwa nilai rata-rata pretest prestasi belajar matematika pada kelas GDL-Kon yaitu 42,96 mengalami peningkatan dari 34,75 menjadi 77,71 pada posttest. Sedangkan, pada kelas konvensional yaitu 39,7 pada pretest mengalami peningkatan sebesar 26,73 menjadi 66,43 pada posttest. Selain itu, berdasarkan pesentase ketuntasan belajar, pada kelas GDL-Kon diperoleh persentase ketuntasan sebesar 3,71\% (1 siswa) yang mencapai KKM pada pretest meningkat menjadi 89,29\% (25 siswa) yang mencapai KKM pada posttest. Sedangkan, pada kelas konvensional diperoleh persentase ketuntasan sebesar 0\% pada pretest meningkat menjadi 64,29\% (18 siswa) yang mencapai KKM pada posttest. Data hasil pretest dan posttest angket self-efficacy matematika siswa untuk kedua kelas disajikan pada Tabel 4.

Tabel 4. Data Hasil Pretest dan Posttest Self-efficacy Matematika Siswa

\begin{tabular}{lcccc}
\hline \multirow{2}{*}{ Deskripsi } & GDL-Kon & \multicolumn{3}{c}{ Konvensional } \\
\cline { 2 - 5 } & Pre & Post & Pre & Post \\
\hline Mean & 81,26 & 93,94 & 79,63 & 79,71 \\
Standar Deviasi & 8,32 & 9,27 & 7,94 & 8,97 \\
Varians & 69,20 & 85,89 & 63,09 & 80,58 \\
Maksimum & 104 & 109 & 105 & 102 \\
Minimum & 65 & 74 & 67 & 65 \\
\hline
\end{tabular}


Berdasarkan Tabel 4 diperoleh bahwa nilai rata-rata self-efficacy matematika siswa pada kelas GDL-Kon dan kelas konvensional sebelum perlakuan (pretest) relatif sama. Namun, setelah diberi perlakuan (posttest) nilai rata-rata self-efficacy siswa pada kedua kelas tersebut mengalami peningkatan. Nilai rata-rata pretest self-efficacy matematika siswa pada kelas GDL-Kon sebesar 81,26 mengalami peningkatan menjadi 93,94 pada posttest. Sedangkan, pada kelas konvensional sebesar 79,62 pada pretest mengalami peningkatan menjadi 79,71 .

Kategorisasi self-efficacy matematika siswa pada kelas GDL-Kon diperoleh untuk siswa dengan kategori self-efficacy sangat tinggi sebesar 3,71\% (1 siswa) pada pretest menjadi $25 \%$ (7 siswa) pada posttest, kategori tinggi sebesar 22,23\% (6 siswa) pada pretest menjadi 64,29\% (18 siswa) pada posttest, kategori sedang sebesar 74,07\% (20 siswa) pada pretest menjadi 10,71\% (3 siswa) pada posttest dan tidak ada siswa yang berada pada kategori rendah maupun sangat rendah. Sedangkan, pada kelas konvensional, siswa dengan kategori self-efficacy sangat tinggi sebesar 3,71\% (1 siswa) pada pretest menjadi $7,14 \%$ ( 2 siswa) pada posttest, kategori tinggi sebesar $25,93 \%$ (7 siswa) pada pretest menjadi $32,14 \%$ ( 9 siswa) pada posttest, kategori sedang sebesar 70,37\% (19 siswa) pada pretest menjadi 60,72\% (17 siswa) pada posttest dan tidak ada siswa yang berada pada kategori rendah maupun sangat rendah.

\section{Analisis Data Inferensial}

\section{Data Pretest}

Analisis data inferensial dalam penelitian ini bertujuan untuk melihat perbandingan rata-rata sebelum dan sesudah diberikan perlakuan. Uji sebelum perlakuan dilakukan untuk mengetahui kesamaan vektor rata-rata kedua kelas ditinjau dari kemampuan berpikir kritis, prestasi belajar, dan self-efficacy matematika siswa. Namun, sebelum itu dilakukan uji asumsi normalitas dan homogenitas.

Uji normalitas dilakukan pada skor data pretest kemampuan berpikir kritis, prestasi belajar, dan self-efficacy matematika siswa yang telah diperoleh. Data hasil uji normalitas multivariat dengan menggunakan uji jarak Mahalanobis disajikan pada Tabel 5.

Tabel 5. Hasil Uji Normalitas Multivariat Pretest

\begin{tabular}{lcc}
\hline \multicolumn{1}{c}{ Kelas } & $\boldsymbol{d}^{\mathbf{2}}<\boldsymbol{\chi}_{\mathbf{2}}^{2}(\mathbf{0}, \mathbf{5})$ & Keterangan \\
\hline GDL-Kon & $55,56 \%$ & Normal \\
Konvensional & $59,26 \%$ & Normal \\
\hline
\end{tabular}

Berdasarkan Tabel 5 diperoleh bahwa persentase nilai jarak mahalanobis $\left(d^{2}\right)$ yang kurang dari $\chi_{2}^{2}(0,5)=2,365974$ untuk kelas GDL-Kon dan konvensional secara berturut-turut yaitu $55,56 \%$ dan $59,26 \%$. Dengan demikian, dapat disimpulkan bahwa data pretest kemampuan berpikir kritis, prestasi belajar, dan self-efficacy matematika berdistribusi normal multivariat.

Uji homogenitas multivariat data pretest menggunakan Box's M. Hasil uji homogenitas data pretest disajikan pada Tabel 6.

Tabel 6. Hasil Uji Homogenitas Pretest

\begin{tabular}{ccc}
\hline Box's M & F & Sig \\
\hline 5,935 & 0,927 & 0,474 \\
\hline
\end{tabular}

Berdasarkan Tabel 6, diperoleh nilai Box's M sebesar 5,935 dan nilai signifikasi sebesar 0,474. Karena nilai signifikasi $0,474>\alpha=0,05$ maka dapat disimpulkan bahwa matriks vektor kovarians pada kelas GDL-Kon dan konvensional sebelum diberikan perlakuan adalah homogen. Karena kedua asumsi telah terpenuhi, maka uji kesamaan vektor rata-rata dapat dilakukan. Hasil uji kesamaan vektor rata-rata kedua kelas disajikan pada Tabel 7.

Tabel 7. Hasil Uji Kesamaan Vektor Rata-rata Kelas GDL-Kon dan Konvensional Data Pretest

\begin{tabular}{cccc}
\hline Effect & Value & F & Sig \\
\hline Hotelling's Trace & 0,049 & $0,825^{\mathrm{b}}$ & 0,486 \\
\hline
\end{tabular}

Tabel 7 menunjukkan nilai signifikasi Hotelling's Trace sebesar 0,486. Nilai signifikasi 0,486 > $\alpha=0,05$, menunjukkan bahwa $H_{0}$ diterima, sehingga dapat disimpulkan bahwa tidak terdapat perbedaan skor rata-rata pretest kemampuan berpikir kritis, prestasi belajar dan self-efficacy matematika siswa pada kelas eksperimen dan kelas kontrol. 


\section{Data Posttest}

Analisis data posttest dilakukan dengan menggunakan uji one sample t test dan uji Manova (Hotelling's Trace). Uji one sample t test digunakan untuk mengetahui keefektifan metode pembelajaran ditinjau dari kemampuan berpikir kritis, prestasi belajar, dan self-efficacy matematika siswa. Namun, terlebih dahulu dilakukan uji asumsi univariat. Hasil uji normalitas univariat dengan uji Kolmogrov Smirnov untuk data posttest disajikan pada Tabel 8.

Tabel 8. Hasil Uji Normalitas Univariat Data Posttest

\begin{tabular}{|c|c|c|c|}
\hline \multirow{2}{*}{ Aspek } & \multicolumn{2}{|c|}{ Sig } & \multirow[b]{2}{*}{ Ket. } \\
\hline & GDL-Kon & Konvensional & \\
\hline Berpikir Kritis & 0,053 & 0,576 & Normal \\
\hline Prestasi & 0,387 & 0,074 & Normal \\
\hline Self-efficacy & 0,895 & 0,559 & Normal \\
\hline
\end{tabular}

Hasil uji normalitas pada Tabel 8 menunjukkan bahwa nilai signifikansi untuk semua kelas $>$ $\alpha=0,05$. Begitu pula dengan uji normalitas multivariat diperoleh hasil yaitu $57,14 \%$ jarak mahalanobis yang kurang dari $\chi_{2}^{2}(0,5)=2,365974$. Dengan demikian, dapat disimpulkan bahwa data posttest normal. Selanjutnya, hasil uji homogenitas univariat disajikan pada Tabel 9.

Tabel 9. Hasil Uji Homogenitas Univariat Data Posttest

\begin{tabular}{lcc}
\hline \multicolumn{1}{c}{ Aspek } & Nilai F & Sig \\
\hline Berpikir Kritis & 11,393 & 0,001 \\
Prestasi & 4,030 & 0.05 \\
Self-efficacy & 0,086 & 0,771 \\
\hline
\end{tabular}

Hasil uji homogenitas data posttest yang ditunjukkan pada Tabel 9 untuk aspek prestasi belajar, dan self-efficacy matematika siswa pada kedua kelas memiliki nilai signifikansi $\geq \alpha=0,05$, sehingga memenuhi asumsi homogenitas. Sedangkan, pada aspek kemampuan berpikir kritis matematika, nilai signifikansinya sebesar 0,001 $<0,05$ yang artinya bahwa data tidak homogen. Namun, hal ini tidak fatal untuk univariat maka proses analisis tetap dilanjutkan (Ghozali, 2011, p. 75). Secara multivariat diperoleh hasil signifikansi $0,055>\alpha=0,05$, artinya data posttest homogen.

Hasil uji asumsi yang telah dilakukan menunjukkan bahwa data posttest telah memenuhi semua asumsi, sehingga pengujian keefektifan metode pembelajaran untuk setiap aspek dapat dilakukan. Hasil uji keefektifan metode pembelajaran GDL-Kon disajikan pada Tabel 10.

Tabel 10. Hasil Uji One Sample t test GDL-Kon

\begin{tabular}{lccc}
\hline \multirow{2}{*}{ Aspek } & \multicolumn{3}{c}{ GDL-Kon } \\
\cline { 2 - 4 } & Nilai t & Sig & Ket \\
\hline Berpikir Kritis & 2,7169 & 0.011 & Efektif \\
Prestasi & 4,2072 & 0.000 & Efektif \\
Self-efficacy & 7,0596 & 0.000 & Efektif \\
\hline
\end{tabular}

Berdasarkan Tabel 10, diperoleh bahwa nilai $t$ untuk aspek kemampuan berpikir kritis, prestasi belajar, dan self-efficacy matematika siswa lebih dari $\left(t_{0,05,27}\right)=2,0518$. Hasil tersebut menunjukkan bahwa $H_{0}$ ditolak. Dengan demikian disimpulkan bahwa metode pembelajaran GDL menggunakan pendekatan kontekstual efektif ditinjau dari kemampuan berpikir kritis, prestasi belajar, dan self-efficacy matematika siswa.

Keberhasilan metode GDL menggunakan pendekatan kontekstual dalam meningkatkan kemampuan berpikir kritis disebabkan oleh karakteristik serta tahap-tahapan dari metode tersebut sangat mendukung terakomodirnya kemampuan berpikir kritis matematika siswa. Tahapan-tahapan dalam metode GDL seperti menstimulus, mengidentifikasi, menganalisis, dan menyimpulkan menuntut siswa mengeluarkan ide dan pikiran mereka serta memiliki relevansi yang kuat dengan setiap aspek kemampuan berpikir kritis. Bertalian dengan itu, (Westwood, 2008, p. 29) menyatakan bahwa dalam metode GDL guru membantu siswa menghubungkan ide-ide mereka. Kondisi ini merupakan salah satu ciri seorang pemikir kritis, dimana mereka mampu memahami hubungan yang logis antara ide-ide (Lau, 2011, p. 2). Sejalan dengan itu, (Cruickshank et al., 2005, p. 271) menyatakan karakteristik metode discovery adalah keterlibatan siswa dalam mengeksplor dan berpikir secara mandiri, sehingga berpotensi pada peningkat- 


\section{Jurnal Riset Pendidikan Matematika, 6 (2), 2019 - 128}

Imaludin Agus

an kemampuan kognitif tinggi, salah satunya kemampuan berpikir kritis. Hal tersebut tentunya sejalan dengan penelitian (Yuliani \& Saragih, 2015) yang menyimpulkan bahwa kemampuan berpikir kritis matematika lebih baik ketika diterapkan metode GDL.

Kaitannya dengan pendekatan kontekstual, (Jhonson, 2014, p. 65) menyatakan bahwa salah satu karakteristik pendekatan kontekstual adalah dapat melibatkan siswa dalam berpikir kritis dan kreatif. Selain itu, hasil penelitian (Kurniati et al., 2015) menunjukkan bahwa pembelajaran CTL efektif meningkatkan kemampuan berpikir kritis matematika siswa. Oleh karena itu, penggunaan pendekatan tersebut sangat tepat untuk meningkatkan kemampuan berpikir kritis siswa. Demikian pula untuk prestasi belajar matematika siswa, metode tersebut efektif karena setiap tahapan pada metode GDL menitikberatkan pada keaktifan siswa menemukan konsep dan prinsip, sehingga siswa dapat mengkonstruksi pengetahuannya yang berdampak pada daya ingat jangka panjang (Hosnan \& Sikumbang, 2014, p. 282). Berdasarkan hasil penelitian (Imawan, 2015; Siregar \& Marsigit, 2015) dapat disimpulkan bahwa pendekatan discovery memiliki pengaruh terhadap prestasi belajar matematika siswa.

Hal penting lainnya adalah penerapan pendekatan kontekstual yang menekankan pada keterkaitan materi pembelajaran dengan kehidupan nyata siswa, sehingga dapat mengetahui penerapan setiap materi dalam kehidupan sehari-hari. Selain itu, pendekatan kontekstual yang salah satunya memuat strategi cooperating menjadikan siswa saling berkomunikasi, berdiskusi, berbagi, dan berinteraksi untuk mewujudkan tujuan bersama. Jhonson (Crowford, 2001, p. 13) menyimpulkan bahwa ketika guru menerapkan pembelajaran yang bersifat kerjasama, maka prestasi belajar siswa meningkat secara signifikan.

Ditinjau dari self-efficacy matematika siswa metode GDL-Kon efektif karena menekankan pada keterlibatan siswa menemukan secara langsung pengetahuannya selama proses pembelajaran serta siswa mengetahui relevansi materi yang dipelajari dengan kehidupan sehari-hari. Hal ini sejalan dengan pendapat McCombs dan Marzano (Curry et al., 2012), bahwa ketika siswa mengetahui fakta bahwa dia adalah agen dalam pembelajaran mereka, proses metakognisi menghasilkan self-efficacy dan memungkinkan siswa untuk mulai menginternalisasi tujuan. Begituvpula pada pendekatan kontekstual yang menitikberatkan pada relevansi materi matematika dengan kehidupan nyata sehingga menjadikan self-efficacy matematika siswa meningkat. Sebagaimana (Pajares \& Graham, 1999, p. 126) menyatakan bahwa self-efficacy merupakan keyakinan atas manfaat matematika dengan kehidupan sehari-hari. Selain itu, (Schneider, 2014, p. 94) mengungkapkan bahwa GDL meningkatkan motivasi intrinsik pada siswa. Dengan motivasi dan rasa ingin tahu yang tinggi maka siswa memiliki keyakinan yang tinggi pula tentang kemampuan dirinya.

Uji keefektifan selanjutnya diperuntukan untuk kelas yang mendapat perlakuan berupa pembelajaran konvensional. Hasil pengujian tersebut disajikan pada Tabel 11.

Tabel 11. Hasil Uji One Sample t test Konvensional

\begin{tabular}{lccc}
\hline \multirow{2}{*}{ Aspek } & \multicolumn{3}{c}{ Konvensional } \\
\cline { 2 - 4 } & Nilai t & Sig & Ket \\
\hline Berpikir Kritis & $-3,7501$ & 0,056 & Tidak Efektif \\
Prestasi & $-1,5033$ & 0,144 & Tidak Efektif \\
Self-efficacy & $-1,1116$ & 0,276 & Tidak Efektif \\
\hline
\end{tabular}

Berdasarkan Tabel 11, pada kelas konvensional diperoleh bahwa nilai $t$ secara keseluruhan kurang dari $\left(\mathrm{t}_{0,05,27}\right)=2,0518$. Melalui hasil tersebut, dapat disimpulkan bahwa $H_{0}$ diterima, maka metode pembelajaran konvensional tidak efektif ditinjau dari kemampuan berpikir kritis, prestasi belajar, dan self-efficacy matematika siswa.

Metode pembelajaran konvensional yang bercirikan guru sebagai pusat informasi serta mendemonstrasikan setiap materi secara langsung kepada siswa, sehingga mengurangi keterlibatan siswa dalam mengakomodir kemampuan berpikir kritisnya. Hal ini tidak sesuai dengan prinsip dasar belajar modern yang mengisyaratkan bahwa pelajaran tidak dapat diberikan begitu saja kepada siswa, akan tetapi siswa sendirilah yang mengkonstruksi, mengolah serta menggunakan pengetahuannya (Hosnan \& Sikumbang, 2014, p. 282). Kondisi ini menjadi penyebab metode pembelajaran konvensional tidak efektif ditinjau dari kemampuan berpikir kritis matematika siswa. Sebagaimana penelitian (Abdurahim, 2016) yang menyimpulkan bahwa metode pembelajaran konvensional tidak efektif ditinjau dari kemampuan berpikir kritis matematika siswa.

Kaitannya dengan prestasi belajar matematika, siswa kurang aktif selama proses pembelajaran, sehingga setiap materi matematika yang dipelajari tidak bermakna dan tersimpan lebih lama di benak 
mereka. Menurut (National Council of Teacher Mathematics, 2000, p. 20), dalam belajar matematika siswa harus dengan pemahaman, secara aktif membangun pengetahuannya sendiri dari pengalaman serta pengetahuan sebelumnya. Hal ini juga sesuai dengan hasil penelitian (Putri \& Santosa, 2015; Siregar \& Marsigit, 2015) bahwa metode pembelajaran konvensional tidak dapat meningkatkan prestasi belajar matematika siswa.

Hal yang sama untuk aspek self-efficacy siswa. Selama proses pembelajaran siswa bersifat pasif mendengarkan, menulis, mencatat, dan mengerjakan latihan soal menjadikan potensi dalam diri siswa tidak termaksimalkan. Kondisi ini juga menyebabkan siswa merasa bosan selama proses pembelajaran yang berdampak pada keyakinan diri mereka atas kemampuan yang dimiliki tidak meningkat. Seperti yang diungkapkan oleh (Iman, 2018) dalam penelitianya bahwa gaya mencatat tidak efektif ditinjau dari self-efficacy matematika siswa.

Uji perbedaan keefektifan metode pembelajaran dilakukan dengan menggunakan uji Manova. Hasil pengujian disajikan pada Tabel 12.

Tabel 12. Hasil Uji Perbedaan Keefektifan GDL-Kon dan Konvensional Data Posttest

\begin{tabular}{cccc}
\hline Effect & Value & F & Sig \\
\hline Hotelling's Trace & 0,731 & $12,671^{\mathrm{b}}$ & 0,000 \\
\hline
\end{tabular}

Berdasarkan Tabel 12, diperoleh hasil uji perbedaan keefektifan metode pembelajaran dengan melihat nilai signifikasi Hotelling's Trace yaitu sebesar 0,000 $<0.05$. Hasil analisis tersebut menunjukkan bahwa kemampuan berpikir kritis, prestasi belajar, dan self-efficacy siswa kelas GDL-Kon dan Kelas Konvensional berbeda secara signifikan. Oleh karena itu, dilanjutkan dengan uji perbandingan menggunakan uji independent t test yang bertujuan untuk menunjukkan metode mana yang lebih efektif ditinjau dari masing-masing variabel. Hasil uji independent t test disajikan pada Tabel 13.

Tabel 13. Keefektifan Metode Pembelajaran Ditinjau dari Masing-Masing Variabel

\begin{tabular}{lcc}
\hline \multicolumn{1}{c}{ Aspek } & Nilai t & Sig. \\
\hline Berpikir Kritis & 4,618 & 0,000 \\
Prestasi & 3,761 & 0,000 \\
Self-efficacy & 5,844 & 0,000 \\
\hline
\end{tabular}

Hasil pada Tabel 13 menunjukkan bahwa untuk setiap variabel, nilai sig. $<\alpha=0,05$, sehinggaa $H_{0}$ ditolak. Dengan demikian dapat disimpulkan bahwa metode pembelajaran GDL menggunakan pendekatan kontekstual lebih efektif dibandingkan metode konvensional ditinjau dari kemampuan berpikir kritis, prestasi belajar, maupun self-efficacy matematika siswa.

Faktor utama yang menjadi penyebab metode pembelajaran GDL menggunakan pendekatan kontekstual lebih efektif dibandingkan dengan metode pembelajaran konvensional ditinjau dari kemampuan berpikir kritis, prestasi belajar, dan self-efficacy matematika siswa yaitu keterlibatan siswa selama proses pembelajaran. Pada metode pembelajaran GDL menggunakan pendekatan kontekstual siswa lebih aktif mengkonstruksi pengetahuannya sendiri serta mengetahui relevansi materi yang dipelajari dengan kondisi nyata yang mereka hadapi. Selain itu, tahapan pembelajaran seperti mengidentifikasi masalah, experiencing, dan menyimpulkan memberikan kesempatan siswa untuk mengeksplor pengetahuannya, sehingga berdampak pada peningkatan kemampuan berpikir kritis dan prestasi belajar siswa. Sedangkan, pada metode konvensional yang menjadikan guru sebagai pusat informasi, sehingga membatasi keterlibatan siswa selama proses pembelajaran yang berdampak pada tidak terakomodirnya proses berpikir siswa. Hal ini bertentangan dengan pendapat (Moore, 2014) bahwa dalam belajar siswa akan mengkonstruksi dan membangun pengetahuannya sendiri melalui pengalaman dan interaksi dengan lingkungan belajarnya.

\section{SIMPULAN}

Hasil penelitian menunjukkan bahwa metode pembelajaran GDL menggunakan pendekatan kontekstual efektif ditinjau dari kemampuan berpikir kritis, prestasi belajar, dan self-efficacy matematika siswa SMP. Metode pembelajaran GDL menggunakan pendekatan kontekstual juga lebih efektif dibandingkan pembelajaran konvensional yang ditinjau dari kemampuan berpikir kritis, prestasi belajar, dan self-efficacy matematika siswa. Berdasarkan temuan penelitian, maka peneliti menyarankan agar dunia pendidikan dapat menjadikan metode GDL dengan pendekatan kontekstual sebagai metode yang 
digunakan dalam proses pembelajaran. Selain itu, bagi peneliti selanjutnya dapat menggunakan metode tersebut untuk aspek kognitif lainnya. Penerapan metode tersebut dapat dilakukan untuk materi yang berbeda, lokasi, serta karateristik siswa yang berbeda dengan penelitian yang telah dilaksanakan.

\section{DAFTAR PUSTAKA}

Abdurahim, A. (2016). Keefektifan model pembelajaran resik ditinjau dari sikap, motivasi, dan kemampuan berpikir kritis matematis siswa SMP. Jurnal Riset Pendidikan Matematika, 3(2), 137-149. https://doi.org/10.21831/JRPM.V3I2.7994

Badan Standar Nasional Pendidikan. (2015). Laporan hasil ujian nasional tahun pelajaran 2014/2015 (Vol. 234).

Badan Standar Nasional Pendidikan. (2016). Laporan hasil ujian nasional tahun pelajaran 2015/2016.

Chukwuyenum, A. N. (2013). Impact of critical thinking on performance in mathematics among senior secondary school students in Lagos state. IOSR Journal of Research \& Method in Education (IOSRJRME), 3(5), 18-25. https://doi.org/10.9790/7388-0351825

Crowford, M. R. (2001). Teaching contextually: Research, rational and techniques for improving student motivation and achievement in mathematics and science. CORD.

Cruickshank, D. R., Jenkins, D. B., \& Metcalf, K. K. (2005). The act of teaching. McGraw-Hill Companies.

Curry, K., Wilson, E., Flowers, J., \& Farin, C. (2012). Scientific basis vs. contextualized teaching and learning: The effect on the achievement of postsecondary students. Journal of Agricultural Education, 53(1), 57-66. https://doi.org/10.5032/jae.2012.01057

Fahim, M., \& Masouleh, N. S. (2012). Critical thinking in higher education: A pedagogical look. Theory and Practice in Language Studies, 2(7). https://doi.org/10.4304/tpls.2.7.1370-1375

Fithriyyati, N., \& Maryani, I. (2018). Science lesson plan evaluation for 7th grade secondary school: A learning process reflection. Psychology, Evaluation, and Technology in Educational Research, 1(1), 9-18. https://doi.org/10.33292/petier.v1i1.17

Ghozali, I. (2011). Aplikasi analisis multivariate dengan program IBM dan SPSS. In aplikasi analisis multivariate dengan program ibm spss 19. Badan Penerbit Universitas Diponegoro. https://doi.org/10.2307/1579941

Hosnan, M., \& Sikumbang, R. (2014). Pendekatan saintifik dan kontekstual dalam pembelajaran abad 21: Kunci sukses implementasi kurikulum 2013. Ghalia Indonesia.

Iman, N. (2018). Efektivitas gaya mencatat linear dan non-linear bersetting saintifik dalam pembelajaran matematika. JNPM (Jurnal Nasional Pendidikan Matematika), 2(2), 233-249. https://doi.org/10.33603/jnpm.v2i2.981

Imawan, O. R. (2015). Perbandingan antara keefektifan model guided discovery learning dan projectbased learning pada matakuliah geometri. PYTHAGORAS: Jurnal Pendidikan Matematika, 10(2), 179. https://doi.org/10.21831/pg.v10i2.9156

Jhonson, E. B. (2014). Contextual teaching and learning menjadi kegiatan belajar-mengajar mengasikan dan bermakna (I. Setiawan (trans.)). Corwin Press.

Johnson, R. A., \& Wichern, D. W. (2002). Applied multivariate statistical analysis. In Pearson Education International. Prentice Hall. https://doi.org/10.1198/tech.2005.s319

Komalasari, K. (2010). Pembelajaran kontekstual konsep dan aplikasi. Refika Aditama.

Kurniati, K., Kusumah, Y. S., Sabandar, J., \& Herman, T. (2015). Mathematical critical thinking ability through contextual teaching and learning approach. Journal on Mathematics Education, 6(1), 5362. https://doi.org/10.22342/jme.6.1.1901.53-62

Lau, J. Y. F. (2011). An introduction to critical thinking and creativity: Think more, think better. John Wiley \& Sons.

Liu, X., \& Koirala, H. (2009). The effect of mathematics self-efficacy on mathematics achievement of high school students. NERA Conference Proceedings 2009, 30. https://opencommons.uconn.edu/nera_2009/30 
Mahmudi, A. (2009). Mengembangkan kemampuan berpikir siswa melalui pembelajaran matematika realistik. Seminar Nasional Penelitian, Pendidikan Dan Penerapan MIPA, 349-354.

Marsigit, M., Rizkianto, I., \& Murdiyani, N. M. (2015). Filsafat matematika dan praktis pendidikan matematika. UNY Press.

Peraturan Menteri Pendidikan dan Kebudayaan Republik Indonesia Nomor 21 Tahun 2016 tentang Standar Isi Pendidikan Dasar dan Menengah, Pub. L. No. 64, Peraturan Menteri Pendidikan dan Kebudayaan Republik Indonesia (2016).

Moore, K. D. (2014). Effective instructional strategies: From theory to practice. Sage Publications.

Muijs, D., \& Reynolds, D. (2005). Effective teaching: Evidence and practice. SAGE Publications.

Muijs, D., Reynolds, D., Soetjipto, H. P., \& Soetjipto, S. M. (2011). Effective teaching: Teori dan aplikasi. Pustaka Pelajar.

Mullis, I. V. S., Martin, M. O., Foy, P., \& Arora, A. (2012). TIMSS 2011 international result in mathematics. TIMSS \& PIRLS International Study Center. https://timssandpirls.bc.edu/timss2011/downloads/T11_IR_Mathematics_FullBook.pdf

National Council of Teacher Mathematics. (2000). Prinsiples and standards for school mathematics. NCTM.

Nitko, A. J., \& Brookhart, S. M. (2011). Educational assessment of students. Pearson/Allyn \& Bacon.

Pajares, F., \& Graham, L. (1999). Self-efficacy, motivation constructs, and mathematics performance of entering middle school students. Contemporary Educational Psychology, 24(2), 124-139. https://doi.org/10.1006/ceps.1998.0991

Putri, R. I., \& Santosa, R. H. (2015). Keefektifan strategi react ditinjau dari prestasi belajar, kemampuan penyelesaian masalah, koneksi matematis, self efficacy. Jurnal Riset Pendidikan Matematika, 2(2), 262. https://doi.org/10.21831/jrpm.v2i2.7345

Schneider, D. K. (2014). Educational (instructional) design models. http://bigbook.or.kr/bbs/data/file/bo02/1535291005_MQ8Nsgjn_Educational_28instructional29 _design_models_Daniel_K._Schneider.pdf

Schunk, D. H. (2012). Learning theories: An educational perspective. Pearson.

Setiadi, H., Mahdiansyah, M., Rosnawati, R., Fahmi, F., \& Afiani, E. (2012). Kemampuan matematika siswa SMP Indonesia menurut benchmark internasional TIMSS 2011 (R. Rahmawati (ed.)).

Siregar, N. C., \& Marsigit, M. (2015). Pengaruh pendekatan discovery yang menekankan aspek analogi terhadap prestasi belajar, kemampuan penalaran, kecerdasan emosional spiritual. Jurnal Riset Pendidikan Matematika, 2(2), 224. https://doi.org/10.21831/jrpm.v2i2.7336

Slavin, R. E. (2014). Educational psychology: Theory and practice. Pearson College Div.

Stevens, J. P. (2009). Applied multivariate statistics for the social sciences. Routledge.

Uside, O. N., Barchock, K. H., \& Abura, O. G. (2013). Effect of discovery method on secondary school student's achievement in physics in Kenya. Asian Journal of Social Sciences \& Humanities, 2(3), 351-358.

Van de Walle, J. A. (2010). Elementary and middle school mathematics: teaching developmentally. Pearson /Allyn and Bacon.

Walpole, R. E. (1990). Pengantar statistika, edisi ke-3 (Introduction to statistics). Penerbit PT Gramedia Pustaka Utama.

Westwood, P. S. (2008). What teachers need to know about teaching methods. Aust Council for Ed Research.

Widoyoko, E. P. (2014). Penilaian hasil pembelajaran di sekolah. Pustaka Pelajar.

Yildiz, A., \& Baltaci, S. (2016). Reflections from the analytic geometry courses based on contextual teaching and learning through geogebra software. The Online Journal of New Horizons in Education, 6(4), 155-166. https://www.tojned.net/journals/tojned/articles/v06i04/v06i04-18.pdf

Yuliani, K., \& Saragih, S. (2015). The development of learning devices based guided discovery model to improve understanding concept and critical thinking mathematically ability of students at 
Jurnal Riset Pendidikan Matematika, 6 (2), 2019 - 132

Imaludin Agus

Islamic Junior High School of Medan. Journal of Education and Practice, 6(24), 116-128. https://iiste.org/Journals/index.php/JEP/article/view/25266

Zimmerman, B. J., Bonner, S., \& Kovach, R. (1996). Developing self-regulated learners: Beyond achievement to self-efficacy. American Psychological Association. 